Article

\title{
The Roman Catholic Tradition in Conversation with Thomas Berry's Fourfold Wisdom
}

\section{Simon Appolloni}

Department for the Study of Religion, University of Toronto, 170 St. George Street, 3rd Floor, Toronto, ON M5R 2M8, Canada; E-Mail: simon.appolloni@utoronto.ca; Tel.: +1-647-504-5122

Academic Editor: Michael S. Hogue

Received: 26 May 2015 / Accepted: 26 June 2015 / Published: 2 July 2015

\begin{abstract}
Taking the threatening anthropogenic global environmental destruction-the anthropocene - as a starting point, this paper examines the Catholic tradition, which has remained relatively indifferent to this looming crisis, asking what might help it to change its focus from a decided human ecology to one that counts the human as an integral part of the larger natural ecology. Thomas Berry, whose teachings underlie this work, suggests that since the tradition has grown out of a cosmological perspective that places the human being at the center of ethical deliberations and separate from the natural world, it needs to rely on other Earth-centered and ecological expressions to help Catholics to discover more harmonious avenues of being on Earth, which he describes as a fourfold wisdom - the wisdoms of indigenous peoples, classical traditions, women, and science. Through a critical weaving of these wisdoms into a conversation with the Catholic tradition, this article examines the efficacy of the fourfold wisdom to transform the tradition into a more Earth-honoring expression. While this work concludes that the fourfold wisdom is effecting change where engaged, it also reflects on the challenges and opportunities this engagement faces in light of current realities within the Catholic tradition.
\end{abstract}

Keywords: Thomas Berry; fourfold wisdom; Catholic tradition; anthropocene; Earth-honoring

\section{Introduction}

Our modern industrial civilization, while having yielded many benefits for human kind, has also brought about the acidification of oceans, the destruction of countless forests, the loss of fresh water, the degradation of soils, and the pollution of the atmosphere. Humans have brought about the sixth 
major extinction in Earth's history and the alteration of our very climate [1]. It is not an exaggeration to state what many environmental thinkers and scientists have been saying for some time now, that humans have become a geological force [2,3]. Scientists are referring to the current geological era as the "anthropocene" to stress the extent to which anthropogenic pressures upon Earth systems are producing disastrous planetary environmental change [1].

Something is seriously amiss with the Roman Catholic tradition if, amidst this continuing ecological destruction of Earth's life systems - and by the work of human hands - it remains relatively indifferent. To be sure, there are some laudable episcopal statements and a number of green initiatives undertaken by various Catholics and Catholic groups [4,5]. Nevertheless, considering the magnitude of planetary environmental change occurring, the tradition, on the whole, whether directly or through complicity by its relative lack of action is, in the words of theologian Cynthia Moe-Lobeda, "uncreating" ([6], p. xvii). Such indifference should be great cause for concern.

Cultural historian and Catholic priest Thomas Berry (1914-2009), whose teachings underlie this article, is equally as direct. Contending that humans as a whole have become a "demonic presence" ([7], p. 209), he suggests that all human institutions should be judged primarily to the degree in which they "inhibit, ignore or foster a mutually enhancing human-Earth relationship" ([8], p. 117). On this basis, his critique of his own tradition is also indicting, citing three spiritual orientations within it that would account for its relative indifference to ecological destruction: (i) a spirituality of alienation from the natural world; (ii) a spirituality of the divine delimited predominantly to verbal revelation, and (iii) a spirituality of justice that is excessively concerned with the human to the exclusion of the natural world ([8], p. 61).

It is for these reasons, Berry states, that the teachings, rituals and sacraments of the Catholic tradition ignore the natural world. The image of God, for instance, is one of a transcendent, personal deity that tends to desacralize the natural world ([9], p. 25). The "[e]xcessive concern with the historical Christ..." as well as an undue concern "with the salvation and the savior personality", are also unhelpful or inadequate" ([10], p. 75), as are the Ten Commandments and Apostles' Creed, since memorizing these teaches Catholics "nothing significant about the natural world" ([10], p. 47). Even the Catholic sacraments, while providing adherents with a sense of the divine and community amongst fellow humans, Berry contends, do little to nurture "any substantial relation with the natural world" ([10], p. 48). Berry further adds that the over-arching belief in redemption communicates to Catholics that they "are not for this world" ([9], p. 26). These spiritual orientations could explain, at least in part, why a recent survey undertaken by the Public Religion Research Institute (PRRI) in conjunction with the American Academy of Religion (AAR), where adherents from major religions within the United States of America were asked whether they were "very concerned" about climate change, "white Catholics" ranked at the bottom of the list, with "white Evangelical" and "Mainline Protestants" ranking higher [11]. ${ }^{1}$

1 I do not wish to place too much weight on surveys here. Of interest within this PRRI/AAR 22 November 2014 survey, however, is the fact that among the three affiliations showing the greatest concern for climate change were "Hispanic Catholics" and "Black Protestants", suggesting that class and poverty issues might account for the discrepancy between "white" and "Hispanic Catholics", less so than theology. Also of note is the finding that those Americans who were unaffiliated to a religion ranked second to the top in being "very concerned". Interestingly, the same ranking order 


\section{The Fourfold Wisdom}

If something is amiss with the tradition, then the question to ask is how might the Catholic tradition change so as to foster more fully the peace and intimacy humans need with the rest of the natural world? To this end, Thomas Berry proposes a fourfold wisdom: the wisdom of indigenous peoples, classical traditions, women, and science. Within these four types of wisdom, he maintains, humans can find more Earth-centred and ecological expressions through which they can uncover a new spirituality of living in continuity and intimacy with creation. Such a spirituality, expressed adeptly as Earth-honoring by Larry Rasmussen, seeks the welfare of the whole Earth, with humans living with the rest of creation in a mutually enhancing manner. ${ }^{2}$ While Berry proposes the fourfold wisdom for society in general, in this article we will apply it directly to one religion. In this way, applying Berry's fourfold wisdom to the Catholic tradition, its rituals, prayers and creeds could begin to reflect and honor the divine presence within the whole of creation, patriarchal systems of domination with their characteristic separation of mind and body could be replaced by a more inclusive whole-Earth community ethos, and Catholics could more readily see themselves as interdependent and interconnected with an evolving universe.

mentioned above was found when the participants were asked about the frequency of clergy leaders discussing climate change, showing "Hispanic Catholics" and "Black Protestants" ranking at the top and "white Catholics" at the bottom. Showing Catholic responses in a different light, a more recent survey (March 2015), by Yale Project on Climate Change Communication, and the George Mason University Center for Climate Change Communication [12] looks at the beliefs, attitudes, risk perceptions, policy preferences on climate change of Catholics, non-evangelical Protestants, and born again/evangelical Christians. Also investigated are the opinions from these groups on Pope Francis's trustworthiness on the issue of climate change. This report shows Catholics (as a whole), to be far more troubled about climate change (certainly more so than "white Catholics" within the PRRI/AAR survey), citing that among the three Christian categories sampled, they are most likely to be aware and concerned about climate change. Again, without assigning too much weight to surveys here, I think some explanation is in order to account for the apparent discrepancy between the two surveys. It is important to note that the Yale survey sample population was less than half of that of the PRRI/AAR survey, and that the former does not distinguish between "white" or "Hispanic" Catholic respondents. Could the subsuming of Hispanic and non-Hispanic Catholics under one category within the Yale survey have skewed the results? This is unclear. Notwithstanding this vagueness, another survey (January 2014), conducted by Latino Decisions for the National Resources Defense Council (NRDC) [13,14], does confirm the importance (suggested within the PRRI/AAR survey) that Latinos within the United States (as a whole and not just Catholic Latinos) do indeed place on climate change issues. Further, the survey found that economic and religious considerations are not driving these environmental concerns. When asked whether "Climate change is causing our communities in Mexico, Central and South America, and the Caribbean to face more dangerous and extreme weather, who often have less resources to respond", for instance, 82 percent said they find this statement convincing. Such findings lend support to my contention that class (and solidarity within that class) and quality of life issues - including poverty, which climate change will exacerbatemight account more for why people have a concern over the environment, and that the Catholic tradition-currently at least - plays less of a role in motivating concern or action.

2 I find Rasmussen's term Earth-honoring helpful as it also embraces Aldo Leopold's Land Ethic to anchor the human within a biocentric and not anthropocentric worldview [15]. While Berry also espouses such a biocentric ideal, he does not see humans - as Leopold does_as just "plain members", assigning to humans instead that being in whom "the universe celebrates itself in conscious self-awareness" ([7], p. 198). 
This article does not deny that within the tradition are promising aspects that can be tapped for a more constructive response to the natural world today. However, these are not enough. The tradition will have to undergo a grave transformation and shed the destructive spiritual orientations mentioned above that are so ingrained in its practices and teachings. The aggiornamento inaugurated by Pope John XXIII at Vatican II sought to re-examine the Catholic tradition in a new light, although working in an uneasy tension alongside this form of renewal, a decided ressourcement has also been articulated within the tradition to this day. In the latter, Catholics return to the sources of their own tradition, "so that the old, original and lastingly valid Traditio does not appear old but newly asserts itself as the message of the gospel" ([16], pp. 338-39).

Berry stresses that our destructive patterns of living cannot be critiqued effectively or sufficiently from within the traditional humanist ethics or religions, as these have arisen out of a cosmological perspective that places the human being at the center of ethical deliberations, separate from the natural world ([17], p. 198). For this reason, the Catholic tradition will need to rely on other wisdom traditions for help; it cannot do it alone. Changing the tradition, indeed all traditions whose cosmological perspectives are not Earth-honoring, will be a monumental task, or "great work", as Thomas Berry puts it [17]. There is much to commend such a great work: with over a billion adherents throughout the planet, the Roman Catholic tradition holds the potential for inspiring a good proportion of the human population to become intimate with Earth and to pursue ecological justice.

One of the more intriguing aspects about this research is that nothing, as far as I can ascertain, has been written about Berry in light of his fourfold wisdom in regards to the Catholic tradition. However, much has been written on Thomas Berry and other aspects of his thinking. Considered by some to be a luminary of cosmological ecological thinking, Berry has gained immense popularity and a faithful following of a passionate, albeit relatively small, core of scholars and environmental advocates who continue to weave his insights into their own work [18].

Through a qualitative literature review that, in a spirit of questioning, and a critical weaving of various types of wisdom into a conversation with the Catholic tradition, the aim of this article is to discern patterns and discrepancies and new insights into the efficacy of Berry's fourfold wisdom. While Berry speaks of many traditions within each of the four wisdoms, only an illustration of each wisdom will be examined here-two provided by Berry himself, the other two inspired by Berry's thinking in some way. The choice of illustrations employed in this article has much to do with their efficacy in elucidating Berry's claim, and the intent of their author to foster some engagement with the Catholic tradition. To be sure, other examples could serve just as well, as Berry has demonstrated ([17], chapter 16). Here, we examine cosmology inspiring a new understanding of the place of humans in the world, a Zen practice revealing a methodology for developing an intimacy with Earth, an indigenous epistemology that helps humans affirm a kinship with all creation, and ecofeminist thinking that formulates a new empowering and inclusive ecclesiology. For each of these, there is a brief discussion of how these different types of wisdoms might inspire one or more of the teachings, rituals or sacraments of the Catholic tradition so that they become more Earth-honoring.

It is chiefly when we weave all four types of wisdom into a communal conversation, however, allowing each type of wisdom not only to clarify and affirm but to qualify and inform the other types of wisdom, that we are presented with a more robust portrayal of what I contend Berry intends with his proposal. For the sake of space, the examples of the fourfold wisdom in practice, in the latter part of 
this article, are limited predominantly to the North American sphere. This article culminates with an assessment of the fourfold wisdom in the form of a conversation with the Catholic tradition in light of current realities within the tradition, and what the future might hold for such a conversation.

\section{The Wisdom of Science: Cosmology}

Thomas Berry avers that the new cosmology being presented by science creates a new context for discerning the sacredness of creation, our communion with the universe and our role within it. Together with cosmologist Brian Swimme, Berry presents the wisdom of science in the form of a story of the universe that can energize us into the new ecological era. Stories, Berry contends, are powerful vehicles for education, healing, guidance and discipline. Throughout human history, from the early Paleolithic and Neolithic periods to classical civilizations of the last five thousand years, humans have been telling stories of the cosmos ([19], p. 1). Berry holds that such cosmologies, presented in the form of stories or myths, have shaped emotional attitudes, consecrated suffering and provided humans with purpose ([7], p. 124). Today, Catholics need a new story with a "functional cosmology" ([17], p. 71), one that cultivates an awareness of the approximately thirteen billion year development of the universe to this point. This, in turn, can help Catholics imagine what it will take to continue the process of creation, "wherein we share our existence with the animals and with all natural phenomena" ([7], p. 2).

\subsection{The Universe Story}

The story-explained here in brief-begins some 13 billion years ago with the expansion of the universe from a single quantum singularity, commonly referred to as the Big Bang though expressed by Berry and Swimme as "cosmogenesis" [19]. Immediately, there was an expansive and differentiating force at work. This force embodied the pervasive insistence to create anew, which means no two things are completely alike. "To be", say Swimme and Berry, "is to be different" ([19], p. 74). Diversity in all its forms, also known as complexity or, in its biological context, genetic mutation, becomes important, for, "were there no differentiation, the universe would collapse into homogeneous smudge" ([19], p. 74). ${ }^{3}$

Along with this differentiating force, gravitation began working to pull the primordial particles together. This ability of particles and entities to relate to other realities is labelled as communion, also referred to as interrelatedness, interdependence or, in its biological context, adaptation or natural selection. Because of its relational underpinnings, communion receives much import from Berry and Swimme who maintain that the universe is bonded. This bonding enabled the first atomic beings of

3 Berry paraphrases Thomas Aquinas (from his Summa Theologica, Prima Pars, Question 105 \& 109), on the value of diversity, arguing, because the divine goodness "could not be adequately represented by one creature alone, he produced many and diverse creatures, that what was wanting to one in the representation of the divine goodness might be supplied by another. For goodness which, in God, is simple and uniform, in creatures is manifold and divided; and hence the whole universe together participates the divine goodness more perfectly, and represents it better than any single creature whatever" ([7], p. 79). Berry suggests from this a theological import, namely that our primary need for the lifeforms of the planet is a spiritual and not simply a physical need: "To destroy a living species is to silence forever a divine voice" ([7], p. 46). This same passage is employed by Pope Francis in his encyclical on the environment, Laudato $\mathrm{Si}$, which we will discuss later in this article. 
hydrogen and helium to form. Within these first billions of years, galaxies also began to form-over one hundred billion that we know of [19]. This process of communion continued in dynamic tension with the differentiating force, which Berry describes as a "creative disequilibrium" ([17], p. 52), which eventually gave rise to single-celled organisms and, later, to the "wild rhythms and melodies...of Johann Sebastian Bach" ([17], p. 53). Berry and Swimme underline that since all living beings, including humans, emerge out of this single community, there must have been a consciousness component of the universe even in primitive form from the beginning.

Consciousness here refers to the interior numinous component that Berry posits is present in all reality, which is the basis of subjectivity, also known as autopoiesis, self-organization, or, biologically, as niche creation. Within this universe, we find structures exhibiting self-organizing dynamics, from autocatalytic chemical processes to the development of single cells, which is why Berry and Swimme can say, "The self or identity of a tree or an elephant or a human is a reality immediately recognized by intelligence, even if invisible to senses" ([19], p. 75). Ultimately, the universe is understood as "a communion of subjects rather than a collection of objects" ([19], p. 243).

\subsection{The Practical Import of the New Story}

Berry ponders the cosmological significance of these three principles of diversity, communion and subjectivity, and concludes that science is teaching us about our coherence within the larger sacred Earth community: "We now experience the universe..., as a self-emergent process that has gone through a long sequence of transformations through the millennia to become the world about us" ([8], p. 83). However, mystery remains. Scientists can tell us what gravity does, but not what it is or where it comes from. Gravity, then, plays an important physical, if not poetic, role in forming communion, for, "without the gravitational attraction experienced throughout the physical world, there would be no emotional attraction of humans to one another" ([7], p. 46). Such a new understanding of the universe "is vastly different from the ever-renewing seasonal transformations of the universe as it was known in prior centuries" ([8], p. 83), Berry contends. This discovery challenges Christian notions that the human is an addendum into the universe: "We ourselves were brought into being through this process. The universe story and the human story are a single story" ([8], p. 83).

Mary Evelyn Tucker suggests that the three principles of differentiation, communion and subjectivity, also "become the basis of a more comprehensive ecological and social ethics that recognizes the human community as dependent upon and interactive with the Earth community" ([20], p. 165), for it helps us to nurture "reciprocity between humans" and foster "reverence between humans and earth" [21]. Nurturing the subjectivity of other subjects, for instance, means that humans have to accept limitations upon themselves. By way of an example, Berry states, "To advance the human economy by subverting the earth economy is an obvious absurdity...there exists a governance too subtle for us to understand" ([22], p. 215).

\section{The Wisdom of Ancient Traditions: The Practice of Zen}

Echoing Berry's sentiments, Ruben L. F. Habito, a former Jesuit priest turned Zen master, posits that the outcome of centuries of anthropocentric and otherworldly attitudes has left our modern society with a grave sense of detachment from the world around us. This, he avers, is no less the case for many 
Catholics who see life on Earth as a mere stepping stone to the afterlife, which is what really matters. Habito believes that such an Earthly detachment has us see the world as "other". Specifically, he states that the practice of zazen, by placing emphasis on the "here", can pull Catholics back to Earth. He further argues that this form of meditative mindfulness can lead Catholics to a deeper ecological connectedness when they partake in communion and share the sacrament of the Eucharist as community [23].

\subsection{The Practice of Zen Underlying Our Interconnectedness}

Zen is quite definite in how one is to practice meditative mindfulness. ${ }^{4}$ Quoting Zen master Dogen, Habito informs us, "There is no enlightenment apart from practice. And since enlightenment is without end, practice is without end" ([23], p. 71). The practice to which he refers is zazen, a single-minded sitting: "one sits, and just sits, breathing in and breathing out, nothing else, with no "purposiveness" or goal-orientedness" ([23], p. 71). Habito places much attention on breathing. He suggests that most of us in our fast-paced world have forgotten the importance of breathing and, indeed, how to breathe. He believes the importance of breathing remained underdeveloped in most Western spiritual writings (with some exceptions) in their accounts of meditation or contemplative practice. Yet breathing is very important: the meditator is invited to experience the fullness of each "here and now" of breath, which produces a stillness or silencing of the mind. Habito also points out how the concept of breathing is underscored in Christian scriptures. In Luke 4:18, Jesus inaugurates his public ministry quoting from Isaiah where the spirit (recall the Latin spiritus means breath), comes upon Jesus so he can "preach the Good News to the poor...to let the oppressed go free", and at the end of his Earthly ministry, Jesus commissions his disciples with the Holy Spirit in a post-Easter encounter by breathing on them (John 20:22). In short, Habito paints Catholic spirituality as a life led in the spirit (breath) of Jesus Christ.

Notwithstanding the common views of the significance of breathing, there is a decided difference in the approach to breathing in Zen practice, which seeks to bring all this abstract and conceptual thinking of spirit down to a very concrete and experiential level through breathing. This practice is then to be absorbed into daily living or, "living fully in the here and now" ([23], p. 118). Doing the dishes, for example, to most of us means getting them clean so that we can move on to something else in the future. Our Western lives are typically directed to some purpose or goal that we or others have set for us. With such an attitude, Habito suggests that we tend to place value on things based on how they serve our purposes or meet our future goals. We treat nature in the same manner, never mindful of the here and now, or of the intrinsic value of animals and ecosystems. Catholics on the whole, Habito asserts, have been living in this way with regard to the afterlife. They live their lives lining up merit points so as to reach heaven, often at the cost of the present. This practice, he feels, benumbs Catholics from the present realities, which, as we discussed above, is that humans are "uncreating".

4 Habito clarifies further that the basic components of the Zen way of life are contained in the last three of the Buddhist Eightfold Path: Right Effort, Right Mindfulness and Right Concentration. The first five steps, he says, can be seen as the preparatory stages to the cultivation of the last three [23]. 


\subsection{The Practical Import of Practicing Zazen}

Meditative mindfulness is not unknown to the Christian tradition especially among its mystics. With the more concrete practice of zazen, Habito maintains, Catholics can experientially uncover this pre-reflective awareness of their interrelatedness and interconnectedness with all of creation. Such awareness can then enter into their everyday lives, thus transforming actions. In a manner that reflects Berry's concern that the Catholic sacraments do little to nurture "any substantial relation with the natural world", Habito links this meditation to the Eucharist. When reflecting upon this bread, Catholics are invited to trace its elements from their source. They see the wheat growing in the fields. The wheat is connected to Earth, nourished by the soil, its minerals, and water and all the living beings within that eco-system such as bacteria and earthworms. Within this web, Catholics can also see the countless human hands that worked to harvest the grain, their families, the truck drivers that hauled the grain, and the bakers that turned it into bread ([23], pp. 106-10). ${ }^{5}$ In this fashion, communion becomes not one between just God and the human, but rather a practice whereby Catholics can begin to sense the communion they share with the energy of the sun and the farmers of the grain. The Eucharist, Habito says, becomes "an invitation to each of us to behold the cosmic dimensions of what is happening right before us" ([23], p 110).

Approaching the sacrament of communion in this manner can help nurture within Catholics the intimacy with nature Berry avers is needed. It is not unlike the communion St. Francis felt when he called the sun, the moon, Earth, and all living creatures his brothers and sisters. Thus, when Catholics pray at Mass, "Blessed are you, Lord God of all creation, for through your goodness we have received the bread we offer you: fruit of the earth and work of human hands, it will become for us the bread of life" [25], they can envision the totality of creation, or in Catholic terminology, the mystical body of Christ.

\section{The Wisdom of the Indigenous People}

While the wisdom of Zen can provide the Catholic tradition with a practice for developing an intimacy with Earth, the wisdom of indigenous peoples can provide Catholics with an epistemology for that same end. Thomas Berry holds that we need to listen to Earth for its guidance into a new Ecozoic era in which human-Earth relationships are mutually enhancing, but he underlines also that we need to regain our primordial language to do so. Humans, on the whole, have lost this capacity of the mythic, imaginative dream experience, exalting the rational process as the only true way to understand things. Berry maintains that the indigenous peoples of the world, for the most part, have not lost the "primordial capacity for language at the elementary level of song and dance wherein we share our existence with the animals and with all natural phenomena" ([7], p. 2). Such a blurring of boundaries between spirit and matter draws from a different epistemology to what our Western culture is accustomed. It grows out of comprehensive models of living among the indigenous people or "lifeways", which is a term employed by John A. Grim, a student of Berry who has devoted much study to indigenous peoples [26]. The indigenous peoples of North America, whose tradition Berry is

5 This practice is reminiscent of the famous Tangerine meditation put forth by Zen master Thich Nhat Hanh, who also makes a link between this meditation and an understanding of the Eucharist ([24], pp. 20-21). 
well acquainted, have maintained a special form of nature mysticism ([7], p. 184), which allows them to perceive a numinous presence within nature and thereby recognize that each aspect of creation has its own inner life or subjectivity. ${ }^{6}$ Moreover, the wisdom of indigenous peoples can serve to help Catholics realize a new way of bringing them, through baptism, into union with the Earth community.

\subsection{The Recognition of a Numinous Presence}

Central to their lifeways is the belief that there exists in this world a powerful spirit presence, which Berry defines as "an awareness of a numinous presence through the entire cosmic order" ([7], p. 184). Native Americans, for instance, understood this presence as Manitou, Orenda, or Wakan Tanka ([19], p. 265). This does not imply that nature is romanticized as some sort of Eden by Berry. The spirit is present through the experience of both the benign and fearsome forces of nature, which does not preclude a love and gratitude for its beauty. The Navaho expressed it as benignly and affectively as "go in beauty" ([17], p. 178). This knowledge of the presence of spirit has deeply formed their lifeways. For instance, the Iroquois Thanksgiving ceremony lasts for days, when each aspect of the natural world is addressed and gratitude is expressed for the benefits that nature bestows upon the people, such as the sun, the wind, and the water. Berry underlines that, in each case, the relationship between the natural phenomena and the human community is very intimate and the gratitude of the people is expressed as they feel themselves sustained by "a cosmic presence that [goes] beyond the surface reality of the surrounding natural world" ([7], p. 39).

Given the presence of spirit in the natural world, then, indigenous peoples have learned to commune with nature as a communion of subjects, not a collection of objects, to use Berry's words [7]. In this way, they hear and listen to the voices of the trees, the birds, the animals, the flowers and the mountains. They address the river and are addressed by the river. Berry believes this predisposition that evokes the power of a shaman is really no different from the predisposition that provokes the insight of the poet or artist ([17], p. 51). It is something primordial within us. This "something" Berry refers to as our genetic coding, which provides the basic psychic and physical structure of our being. It is our genetic coding that bonds us with the larger dimensions of the universe ([7], p. 96). This way, the Native American peoples strike their drumbeats as the rhythms of Earth. They listen to the wind and feel the refreshing rain not as inconveniences to escape from as quickly as possible, but as words from the Wakan Tanka. ${ }^{7}$

\subsection{The Practical Import of a Different Epistemology}

It is apparent that Berry is asking Catholics to take into consideration an epistemology that is radically different than one to which arguably many are familiar. Too many humans have forgotten a "liturgy" of song and dance where, in consideration of the stars splashed across the heavens at night, in

6 Thomas Berry can speak with some authority on this subject. He taught at both Fordham and Columbia universities on American indigenous traditions, and has been received well by native groups in North America and with the Tboli people in the Philippines [27].

7 Related to listening to nature as explained above, the indigenous peoples have also held on to dreaming as a deep way of experiencing the world around them. Berry likens the dream process to a groping or a feeling of something perceived that draws us on to a further clarification of our understandings and our activity ([17], pp. 164-65). 
listening to the song of the lark, and in experiencing the power of a storm, humans are taken into a state of elation and awe. Yet, Berry's engagement with indigenous wisdom might help Catholics to perceive a numinous presence within nature and thereby recognize that each aspect of creation has its own inner life or subjectivity. The indigenous tradition, as discussed above, challenges Catholics to reconsider their delimiting of the sacred to only a few aspects of creation.

Taking baptism, for example, which currently serves to bring Catholics into a relationship with the divine as well as within the religious (human) sacred community, Berry suggests extending this bond to Earth ([10], pp. 47-49). He mentions the Omaha people of North America who have a ceremony that presents an infant to the four directions of the universe. Presenting the child to the heavens, the atmospheric world, the Earthly world and the subsoil world, they implore the spirits to make the path of the child smooth. The ceremony calls upon the trees, air, waters, animals and insects to take care of the child. This bonding extends the human community not only to Earth but to the universe community.

\section{The Wisdom of Women}

Thus far, all these wisdom traditions have spoken to one or more expressions found within the Catholic tradition of an escapism where humans seek to transcend their Earthly existence. It is with the wisdom of women, however, that Catholics can gain an understanding of the dualist attitudes that underscore such thinking, leading to a domination of peoples and of Earth. Such a wisdom of women comes to us as feminist, ecological, and liberationist theologies coalesce in what we know as ecofeminism [28]. Rosemary Radford Ruether is among the first ecofeminists to demonstrate the interconnections between the domination of women and the domination of nature. Trained as a theologian in the classics and patristics, she reconstructs the circumstances that have led to our patriarchal realities today, exposing the myth of a God-ordained patriarchal structure of society and church, and shows how the system of domination of women and nature is actually rooted in a larger patriarchal system that grew out of social cultural settings some 6000 years ago. Ruether borrows from the work of feminist Brazilian theologian Ivone Gebara who, in contrast to the triumphalist-and patriarchal - notion of King and Saviour, presents Jesus as an antimessiah insofar as our salvation is found in Earthly communion, returning to our embodied selves away from escapism and domination. In the end, Ruether outlines a new ecclesiology or way of being in community where the voice of God can also be heard in creation.

\subsection{Rising above Patriarchy}

Ruether identifies the creation stories of the Babylonians, the Hebrews and the Greeks as having particular influence in fostering patriarchal norms within the Christian world ([29], Chapter 1). Each myth exemplifies the male resentment of women and, in the case of the Greek creation myth, we begin to see the mark of an escapist mentality that views women, Earth and all that are corporeal or finite as being vastly inferior to the transcendent and eternal represented pre-eminently in the male. While early Christianity struggled to curb the more radical elements of these creation stories by affirming from the Hebrew story the "goodness" of the body and Earth as God's creation, and conceding that women also possess a redeemable soul in God's image, it retained, however, the Hebrew and the Greek 
identifications of the cosmos and the body with a patriarchal hierarchy. These stories lead to ambiguous interpretations on the value of women and Earth. ${ }^{8}$

Within this worldview, Ruether paints a picture of women possessing an alleged propensity to "mess things up" because of their bodily nature. Augustine, for instance, taught that femaleness itself represents an inferior bodily nature and that a woman does not even possess the image of God in herself, but needs the male for her fulfillment [30]. In this way, the Christian story perpetuates the male resentment toward women. Since it was Eve who initiated the primal disobedience to God, all men are justified in their scapegoating of women for losing "man's" original immortality ([29], p. 140). Ruether believes that understanding this scapegoating of women for losing "man's" original immortality is crucial to understanding the patriarchal pathology that continues within the Christian tradition. According to our story, Adam, at first was able both not to sin and not to die. Through sin - initiated by a woman, chosen by a man-this immortal perfection was lost. This is why redemption for Catholics means escaping this finite world. Earth and the finite, but renewable, life become shunned. The way to ascend the mortal life is to negate it and all that represents it. Women as birth-givers represent the human's finite origins and the realities of the human's Earth-bound pains and limits.

It was within this context that a dualism flourished within Christianity, separating the spiritual from the carnal, the holy from the unholy and the immortal from the mortal. The distinction matters, since on the ideological-cultural level women are said to be "ccloser to nature' than men, and more aligned with body, matter, emotions and the animal world" ([31], p. 77). This closer proximity to the material world has been used to justify the claim that women lack the capacity for intellectual and leadership roles, and leaves them, on the socio-economic level, "relegated" to the sphere of reproduction, cleaning, food preparation and the like.

Moreover, Ruether finds the prominent Christology within Catholic doctrine corresponds to this patriarchal and dualist scenario, "where a heroic warrior will come and deliver"-read helpless - "victims from oppression, punish the oppressors and create an ideal earth freed from sin and want" ([30], p. 107). Such a myth only echoes the Roman Catholic escapist ethos and serves to reproduce rather than break the cycle of violence in the world. In contrast, Ruether offers a radically different worldview and Christology that would have men overcome their illusions of autonomous individualism and their resultant quest for power over others. She finds support for her convictions in the Christology and Soteriology of feminist theologian Ivone Gebara [30]. Gebara looks at Jesus as the one who called people away from both the madness of escapism and domination to their true selves into a community of mutual service. In Gebara's Christology, Jesus stands as the antimessiah, calling upon the powerful to repent and enter into a new Earth community of mutuality.

\subsection{The Practical Import of Re-Thinking Christology}

In keeping with Berry's concern about Catholicism's emphasis on a heavenly redemption, both Gebara and Ruether move away from excessive emphasis on the classical figure of the Saviour, the

8 Ruether points to Gal 3:28, where, in Christ, there is no more male or female, Jew or Greek, slave or free, and compares it to 1 Tim 2:11-15, where women are exhorted to keep silent and have no authority over men in the Christian community, as they were created second and sinned first [30]. 
hero or King, and invest in a salvation in the here and now. ${ }^{9}$ Ruether suggests that real salvation lies in our dismantling of unjust systems on Earth that give power and privilege to one class over another at the expense of most humans and life-sustaining balances in nature [30]. However, salvation, as it is understood here, is inclusive of the biotic community, since dismantling of unjust systems on Earth means that humans cannot overlook the environmental devastation that plagues the majority of creation. Ruether explains the integral nature of environmental and social concerns:

Converting our minds to earth cannot happen without converting our minds to each other, since the distorted and ecologically dysfunctional relationships appear necessary, yet they actually support the profits of the few against the many. ...Any ecological ethic must always take into account the structures of social domination and exploitation that mediate domination of nature and prevent concern for the welfare of the whole community in favor of the immediate advantage of the dominant class, race, and sex ([33], p. 93).

Gebara takes this thinking further and asks, "Why not open up our understanding of 'salvation' to a broader process, one that is going on... in people's daily lives, in the midst of the 'ordinary' things that make up the fabric of our lives" ([34], p. 180)? In this manner, in contrast to the patriarchal readings of the Gospels, which have insisted that we centre our attention on what Jesus did or said, Gebara suggests Catholics pay attention to the sinful nameless woman or the man with a withered hand or the paralytic, who are found in the Gospels ([34], Chapter 5).

With this more arguably biocentric and liberationist understanding of salvation, Gebara and Ruether are offering a logic of relatedness, of humans in relation to themselves and their environment. With the above Christology, Gebara and Ruether seem to offer Catholics a spatial metaphor of a circle to replace that of a pyramid in how currently they might relate to one another and creation, a salvation represented not as an Earthly flight but as offering our presence of tenderness and mercy to all Earthly creatures, here and now.

\section{Assessing the Conversation}

We have discussed how the wisdom of science can provide the tradition with a new ontology wherein Catholics imagine a self-emergent cosmos as a communion of subjects. The wisdom of Zen can impart a methodology for discerning an integral relationship Catholics can develop with creation.

9 Readers might note that the term salvation instead of redemption is used here. This is deliberate, as Ruether uses the terms interchangeably. We can take, for example, how Ruether ends her book Introducing Redemption in Christian Feminism [32]. In reciting the Beijing Women's Conference in 1995 as being all the redemption needed, she suggests, as well, that maybe the idea of redemption should come to an end, or at best be understood like this: Bread. A clean sky. Active peace. A woman's voice singing somewhere. The army disbanded. The harvest abundant. The wound healed. The child wanted. The prisoner freed. The body's integrity honored, the lover returned...labor equal, fair and valued. No hand raised in any gesture but greeting. Secure interior-of heart home, and land - so firm as to make secure borders irrelevant at last ([32], p. 120). I do not suggest here that Ruether willingly conflates the terms - thus retaining a theological distinction between the terms for traditional theological purposes; rather, she wants to re-think our use of the notion redemption, and play up its liberation elements while downplaying its salvific (other-worldly) elements. Reasons why notwithstanding, I think it reasonable, for our purposes, to understand redemption, salvation and liberation, with regard to Ruether's ethical vision, as being virtually interchangeable terms. 
The wisdom of indigenous peoples can reveal a forgotten epistemology so that Catholics can discover how to live in harmony with the world around them. Finally, the wisdom of women can nurture an empowering ecclesiology that is inclusive of the concerns and wellbeing of the entire natural world, sparking ecological justice. All four wisdoms, in varying degrees, challenge the current spiritual orientations of the Catholic tradition and their excessive valuing of the human above the other-than-human, their constant pointing to a future paradise, or their delimiting of the presence of the divine. Further, all four wisdoms, as presented here, whether through prayer, ritual, a general sacramental view of the universe, or through a particular Catholic sacrament, affirm that humans are first and foremost Earthlings, living on a sacred interrelated and interconnected planet.

To be sure, aspects of the types of wisdom presented above are not without critique. For instance, Ruether's strong emphasis on the person and community as a source of one's own salvation, and her severe downplaying of any afterlife, allows her to speak of salvation as the transformation of the human into life-giving relationships - and not as any form of escape to the afterlife. Theologian Steven Bouma-Prediger questions whether one can speak of a Christian eschatology only in such Earthly terms [35]. This is certainly an important issue for Catholics. To be fair to Ruether, her rationale for proposing such an Earthly salvation appears more didactic than doctrinaire. Nowhere does she deny an other-worldly eschatology, at least not explicitly; it is simply put aside for the more immediate goal of greening her tradition ([36], p. 7).

For our appropriation of indigenous wisdoms, we have to inquire whether Berry avoids romanticizing them, eschewing simplified appropriations of already shunned "others" and their ways of knowing the world. American Indian theologian and scholar George Tinker, for instance, critiques North American "New Age" appropriations of Native American Beliefs, yet Tinker finds merit in dreaming a new future for the North American continent where community as a whole (inclusive of the natural world), and not solely the individual, is nurtured and preserved. Interestingly, Tinker ties the liberation of the American Indian to that of Euro-Americans, underlining that the latter's liberation must be rooted in confession, repentance and regret [37]. Cognizant of such provisions, Native American educator Gregory Cajete holds that indigenous peoples around the world have much to share and to give to non-indigenous society as they search for paths to rekindle a relationship with the environment, and to one another in community [38].

Addressing this issue of appropriation, John Grim affirms that a balanced understanding of the cultures of any indigenous peoples recognizes that any evaluation we have of their environmental practices must be assessed in light of how they position themselves in a relationship with the land, waters and larger biotic community which, he concludes, Berry does do ([27]; [39], p. 199). Moreover, Grim suggests that Berry's rejection of romantic stereotypes explains why Berry has received many warm exchanges with indigenous peoples. Grim adds that Berry recognizes how indigenous peoples have been dealing with complex and often tremendous issues of change and transformation [27].

In proposing a "new story", we might also question whether such a comprehensive or grand narrative opens Berry to criticism of espousing a one-size-fits-all story of modern thought [40]. Heather Eaton and Lisa Sideris, for instance, have raised doubt on this aspect of Berry's thinking. Eaton speaks of the "ambiguous dialectic" that exists between the micro and the macro ethical perspectives implied in this new story [41]. Using the example of a sinking ship — the Titanic, in fact-Berry has suggested we have appreciation for the daily concerns of the ship - its micro concerns, which include the welfare of 
individuals - in conjunction with the more pressing concerns of saving the ship - the macro dimension. ${ }^{10}$ Though Berry does engage the two dimensions together in his writings, Eaton feels he places far too great a concern upon the macro rather than the micro ethical dimensions. Eaton ponders how his approach could be interpreted by others and concludes, "One can experience great pleasure in rethinking the cosmological horizon, and avoid addressing the urgent, difficult and entangled problems as seen from the ground". Poignantly, Eaton concludes, "Obviously it is not those who are walking for days for water who are researching cosmological questions" ([41], p. 164).

Lisa Sideris focuses her critique on the mythopoeic form in which Berry and Swimme present the universe story. She questions whether it is likely to engender the environmental ethos they seek to cultivate [42]. Of note, Sideris's primary targets are other advocates of epic evolutionary hegemonic narratives that support a scientific materialism that seeks to displace religious traditions (noting E.O. Wilson's turn to consilience as an example). Swimme and Berry's reading, she does grant, is far more humble. Notwithstanding her caveat, on the matter of myth, philosopher Mary Midgley insists - along the same line of reasoning used by Berry - that myths are vital to our understanding of the universe: "We are accustomed to think of myths as the opposite of science", she states, "but, in fact, they are a central part of it: the part that decides its significance in our lives. So we very much need to understand them" ([43], p. 1). Myths, Midgley concludes, shape meaning in our world.

Concerning the above critiques, and anticipating others on the wisdoms as presented above, it should be kept in mind that Berry intends that there be an open and frank conversation amongst all four wisdoms, never that one wisdom be engaged uncritically in isolation. This is important to note, since, "Each has its own distinctive achievements, limitations, distortions, its own special contribution toward an integral wisdom tradition that seems to be taking shape in the emerging twenty-first century" ([17], p. 194). Such an integral wisdom, then, cannot come about by merely grafting one wisdom upon another. In the examples cited above, each wisdom should be allowed to inform, affirm and qualify the others. In this way, the concerns and dynamics of ecofeminist thinking inform the wisdom of science by critically dialoguing with its claims. When Ruether challenges various anthropo- and androcentric expressions of the Greek and Hebraic creation stories, she receives affirmation on this from the wisdom of science and its understanding of the principles of diversity, subjectivity and communion. When Gebara considers Jesus as the antimessiah, she addresses Eaton's concern above by maintaining that Catholics not forget the daily struggles of individuals to survive and to maintain their dignity. The concerns raised by Eaton qualify the ambiguous dialectic found within the universe story by limiting its macro dimension. Finally, the practice of zazen affirms the ecofeminist Earthly salvific import, with its "here and now" perspective.

Whether espousing an Earthly salvation, the universe as sacred, or whether referring to Manitou or Holy Spirit, Berry insists humans need the fullest of expressions to move into the Ecozoic era, "when humans will be present to the planet as participating members of the comprehensive Earth community" ([17], p. 8). In short, Berry's fourfold wisdom — modelled here-is ostensibly an open and frank broad conversation that speaks to the achievements, limitations and distortions of all the wisdoms engaged. Such an exchange is vital to Berry's aim in transforming destructive spiritualities. In the words of theologian David Tracy, "There is no intellectual, cultural, political, or religious

10 This idea of the Titanic as metaphor was developed by Berry ([17], chapter 9). 
tradition or interpretation that does not ultimately live by the quality of its conversation" ([44], p. 6). Berry offers further strategies for assisting Catholics in their conversation with the fourfold wisdom. An important one we have already discussed with the wisdom of science: the understanding of diversity and communion as principles of the cosmos, underscore the diversity and unity of religions. When Berry and Swimme say "to be is to be different", as discussed above, this principle applies not solely to particles and stars, but to human institutions as well. The conversation can be further facilitated by distinguishing between the microphase membership to the Catholic tradition and the macrophase inspiration that arises from all religious traditions, by recognizing the qualitative differences in religions and promoting these differences, and by recognizing the creative dynamics that are already underway amongst religions and other wisdom traditions ([8], p. 23).

\section{Assessing the Fruits and Challenges of the Conversation}

The more pertinent question to ask at this juncture is whether this conversation amongst the various wisdoms is taking place within the Catholic tradition and whether it is bearing fruit. While an exhaustive survey is not possible, it is not necessary in order to confirm that such a productive conversation is indeed taking place in a number of different Catholic domains; however, it is not occurring widely within the tradition, and this conversation has faced some barriers from the Church hierarchy.

Inspired by Thomas Berry's thinking and by the thinking of ecofeminists such as Charlene Spretnak, Ivone Gebara and Vandana Shiva, many North American Catholic women's religious orders currently apply principles of ecological sustainability to their lands and buildings [45,46]. Actually, it is amongst these women religious that the most profound conversation amongst the fourfold wisdom can be found. While there is an emphasis on honoring "women's wisdom", as we discussed in Section five, the wisdoms of science, indigenous peoples, and ancient (eastern and western) wisdom traditions are also engaged [47]. Sarah McFarland Taylor, whose ethnographic study describes the work of many North American Catholic "green sisters" and their engagement in environmental issues, writes that it is not uncommon for these sisters to have a daily regimen of tai-chi-chuan, yoga or some form of body prayer that makes explicit connections to Earth ([45], p. 114). Inspired by the "new story", as discussed in Section two, cosmic liturgies are celebrated in some monasteries celebrating dawn, dusk, solstices and equinoxes ([45], Chapter 8). At the Monastery of St. Gertude, Cottonwood, Idaho, the women religious created, a multi-media project called "The Passion of the Earth" that blends the traditional Catholic Stations of the Cross devotion and the "new story" as presented in the work of Thomas Berry [48]. Some women religious have set up eco-training centres to help others learn from their experience. A notable site for ecological spirituality and learning is Genesis Farm located in Blairstown, New Jersey. Founded by Sr. Miriam Therese McGinnis in the 1980's, this centre has become a major education centre for ecospirituality and justice [46,49]. Such thinking has even spread to hospitals - one of the major ministries of women religious - where ecological principles of waste recycling and energy and food conservation are applied ([46], p. 196).

In other Catholic contexts, we find further examples of the engagement of one or more of the fourfold wisdom. Similarly inspired by Berry's "new story", the Ignatius Jesuit Centre of Guelph, Ontario has created a spiral meditative walk that represents the Stations of the Cosmos, which depicts significant "moments of grace" in this cosmic story [50]. At this same Centre, a retreat entitled "The 
Greening of The Spiritual Exercises" included among its events a smudging ceremony [51]. In the Archdiocese of Regina, Saskatchewan, it is not zazen, as we discussed earlier, but Holy Yoga Classes which, according to their website, Catholics can practice: a blend of " $100 \%$ Jesus and 100\% yoga" [52]. Along the same line of thinking, Bishop Raffaello Martinelli of the Diocese of Frascati, Italy, who once collaborated with then Cardinal-Prefect of the Congregation for the Doctrine of the Faith, Joseph Ratzinger (who later became Pope Benedict XVI), has recently voiced an openness (with provisions), to eastern meditation practices amongst Catholics, citing the Vatican II document Nostra Aetate, which states, "The Catholic Church rejects nothing that is true and holy in these religions" [53].

Redolent of the blurring of boundaries between spirit and matter, and the need to listen to Earth for its guidance, as we discussed in Section four, Sr. Priscilla Solomon, CSJ, an Ojibway First Nation woman and Sister of St. Joseph of Sault Ste. Marie, regularly applies aboriginal teaching and symbols, such as a revised Anishinaabe water ceremony, or the medicine wheel in order to promote social and environmental justice [54,55]. At Saint Regis Catholic Mission Church on the Canadian side of the Akwesasne Reservation, one can find a blend of elements of Mohawk indigenous spiritual practices, such as smudging and prayers to the creator, into the rituals of the Catholic faith [56]. A similar practice has been occurring in the Roman Catholic Diocese of Mackenzie-Fort Smith, where smudging with sweetgrass, drumming and talk of the four directions occurs within a Catholic Mass [57].

In the instances above where indigenous wisdom is engaged, the appropriations of symbols or practices seem to occur predominantly where there are large numbers of parishioners who are indigenous and not necessarily by non-indigenous Catholics. This phenomenon, of course, could be due to a sensitivity Catholics have to the appropriation of symbols and practices of a people long colonized by western culture, including by their own faith tradition. However, the relative disengagement with indigenous wisdom (compared to the other three), could also be due to a resistance emanating from the Catholic hierarchy. The Vatican document, "Jesus Christ the Bearer of the Water of Life: A Christian Reflection on the "New Age"" [58], for instance, brands many of the fundamental features of indigenous beliefs under the broad category of "New Age", which affectively quells engagement with this wisdom. In parts of the same document, it becomes evident that any reflection upon non-Christian-traditional worldviews is viewed by the Vatican as being hostile to Christianity. The stance here, as indicated below, is unambiguous: Catholics are not to delve into indigenous traditions.

In the great wave of reaction against traditional religions, specifically the Judaeo-Christian heritage of the West, many have revisited ancient indigenous, traditional, pagan religions...From the point of view of Christian faith, it is not possible to isolate some elements of New Age religiosity as acceptable to Christians, while rejecting others... Since the New Age movement makes much of a communication with nature, of cosmic knowledge of a universal good-thereby negating the revealed contents of Christian faith - it cannot be viewed as positive or innocuous...It is therefore necessary to accurately identify those elements which belong to the New Age movement, and which cannot be accepted by those who are faithful to Christ and his Church [58].

In a similar pushback to other wisdoms, we could mention a letter written in October 15, 1989 by then Cardinal Ratzinger, which addresses some aspects of Christians engaging with eastern meditation, 
cautioning that, "It can degenerate into a cult of the body and can lead surreptitiously to considering all bodily sensations as spiritual experiences" [59]. Years later, as Pope, he sent a stronger message to Catholics, warning them of the grave dangers brought on by biocentric thinking, while reinforcing anthropocentric doctrine. In his 2010 Message for World Day of Peace Pope Benedict wrote,

If the Church's magisterium expresses grave misgivings about notions of the environment inspired by ecocentrism and biocentrism, it is because such notions eliminate the difference of identity and worth between the human person and other living things. In the name of a supposedly egalitarian vision of the "dignity" of all living creatures, such notions end up abolishing the distinctiveness and superior role of human beings [emphasis added]. They also open the way to a new pantheism tinged with neo-paganism, which would see the source of man's salvation in nature alone, understood in purely naturalistic terms [60].

Concerning the wisdom of women, we can turn to a more recent endeavor undertaken by the Vatican Congregation for the Doctrine of the Faith, which opened up in 2008 a "Doctrinal Assessment of the Leadership of the Conference of Women Religious" (LCWR: association of the leaders of congregations of Catholic women religious in the United States). The assessment raised much controversy amongst American Catholics and women religious as well. The findings from the Vatican speak, among other things, of a "prevalence of certain radical feminist themes incompatible with the Catholic faith in some of the programs and presentations sponsored by the LCWR" [61]. The assessment ended in early 2015, seemingly more amicably, and rather quietly under the leadership of Pope Francis [62,63].

It is important to note from the above that there appear to be discrepancies emulating from the Church hierarchy, if not in message, at least in tone. The document, "Jesus Christ the Bearer of the Water of Life", for instance, does not quite resonate in tone with the teachings from Nostra Aetate. In addition, the statement above made by Bishop Martinelli seems to disagree - again, at least in tone - with the letter written by then Cardinal Ratzinger. That this short survey points to the existence of an ambiguous relationship between the Catholic tradition and other wisdom traditions is not shockingly new. What is important here is to inquire whether, given this ambiguous reception, the fourfold wisdom conversation will continue, and whether it will go on to bear further fruit.

While a direct cause and effect is unfeasible to measure, from the examples noted above, it does appear that where the conversation is occurring, green thinking and action do follow. While it is not clear the extent to which Berry's writings inspired each of these conversations, we nevertheless find Catholics engaging one or more of the four wisdoms identified by Berry. Compared to the aforementioned spiritual orientations that Berry avers render Catholics relatively indifferent to ecological destruction, those participating in the conversation are clearly concerned about the destruction of all life brought about by human actions.

Still, considering the sheer numbers of Catholics on the planet, the conversation is occurring on a relatively small scale. Moreover, the transformations that we see taking place stem from and are put into practice, in large measure, by theologians, ethicists and other Catholic scholars and church faithful 
concerned about the planetary crisis, and rarely do they flow from the church hierarchy. ${ }^{11}$ Perhaps, for a tradition that is historically sensitized to taking its cues from episcopal teaching and leadership, ${ }^{12}$ the recently released papal encyclical on the environment, Laudato Si, by Pope Francis - the first encyclical to deal exclusively on the matter-might prove to be more galvanizing. Set strategically to inspire the December 2015 UN Conference of the Parties meeting in Paris, and to shore up a visit by the Pope to the United Nations where he will address the General Assembly, expectations by many green Catholics are already high [66] ${ }^{13}$. Initial reactions to the document suggest that the encyclical could indeed influence the views many Catholics have toward the environment [70].

In keeping with our analysis of Berry's fourfold wisdom, however, the full efficacy of the encyclical will rest, in large measure, on the degree to which it incorporates the more Earth-honoring expressions articulated richly in other wisdoms as discussed in this article. The approach put forth by Francis, then, will have to address the three spiritual expressions that Berry maintains keep the tradition indifferent to the environmental destruction occurring. Hence, instead of a decidedly anthropocentric human ecology that has been woven into the fabric of the Catholic tradition, as expressed by Francis's predecessors, ${ }^{14}$ one should find an integral ecology which eschews any excessive valuing of the human above the other-than-human, while situating the human and human endeavours squarely within the larger natural world. Moreover, the presence of the divine should not be delimited predominantly to verbal revelation.

In fact, we find within Laudato $\mathrm{Si}$, all these points to a large degree: while Francis does not "deprive human beings of their unique worth" (9), at the onset, he does underline that humans are "dust of the earth...our very bodies...made up of her elements..." (2), calling our planet our "homeland" (164), which is "a constant source of wonder and awe" (85); while eschewing forms of pantheism, Francis nonetheless states that "we can see God reflected in all that exists..." (86); finally, evocative of Berry's notion that we exist amidst a communion of subjects, Francis links the "cry of the earth" to the "cry of

11 This sentiment is shared by John Hart who sees this to be a historical pattern within the tradition. Discussing the more progressive green initiatives and thinking within the tradition that are stemming from Catholics who see the Earth as having intrinsic and not only instrumental value, Hart writes, "Such developments in Catholic thought rarely, if ever, originated from the church hierarchy; their primary source was the theologians, ethicists, and other scholars who became aware of scientific studies that indicated a developing global environmental crisis and in response began to promote care for earth and respect for earth's biosphere" ([64], p. 66).

12 I do not suggest here that Catholics necessarily follow episcopal teachings or that they are always cognizant of specific teachings. I speak more to the predisposition, on the whole, that Catholics have to contemplating episcopal teachings. In fact, on certain moral issues, many Catholics ignore teachings. A 2014 Vatican initiative to gauge the sentiments of Catholics on family and moral issues found that their "knowledge of conciliar and post-conciliar documents on the Magisterium of the family seems to be rather wanting". Citing examples such as "birth control, divorce and remarriage, homosexuality, cohabitation, fidelity, premarital sex, in vitro fertilization", the report from bishops around the world goes on to say, "many respondents confirmed that, even when the Church's teaching about marriage and the family is known, many Christians have difficulty accepting it in its entirety" [65].

13 Many pundits have already contributed to a discussion on Pope Francis's encyclical, conveying either fears or hopes (depending whether they are in favor or against the status quo machinations of the free market economy) that the encyclical will galvanize Catholics into action [67-69].

14 Apart from the writings of Pope Benedict that we have briefly discussed here, those of Pope John Paul II are also decidedly anthropocentric [71]. 
the poor" (49), adding that "it would also be mistaken to view other living beings as mere objects subjected to arbitrary human dominion" (82). Moreover, in the encyclical, Pope Francis seems to open the doors to what we understand as Berry's fourfold wisdom when he says, "If we are truly concerned to develop an ecology capable of remedying the damage we have done, no branch of the sciences and no form of wisdom can be left out, and that includes religion and the language particular to it" (63), and "We need to take up an ancient lesson, found in different religious traditions and also in the Bible. It is the conviction that "less is more"' (222) [72].

While the encyclical above underlines the interconnectedness of all that exists, and while it is certainly more Earth-honoring than previous papal teachings on the same subject, the Catholic tradition, as we discussed earlier, will still need to undergo a grave transformation and shed the destructive spiritual orientations that are so ingrained in its practices and teachings. Will a single document be enough to transform an entire tradition, its teachings, rituals and sacraments? This is to be seen.

\section{Conclusions}

We began this article by describing the relative silence from the Catholic tradition as humans continue to destroy Earth life systems. It was suggested that since the tradition has grown out of a cosmological perspective that places the human being at the center of ethical deliberations and separate from the natural world, it needs to rely on other Earth-centered and ecological expressions to help Catholics in discovering more harmonious avenues of being Earthlings. This engagement with the fourfold wisdom, as our short demonstration shows, holds potential to transform the tradition into an Earth-honoring expression, one that eschews the excessive valuing of the human above the other-than-human, while situating the human and human endeavours squarely within the larger natural world, celebrating the presence of the divine within creation, as well as beyond it. For the fourfold wisdom to be fully effective, we showed how each of the wisdoms - science, women, indigenous and ancient—need to be engaged simultaneously, as each limits, challenges and/or contributes its own special understanding toward an integral wisdom tradition.

In the end, whether sanctioned or not, Catholics are engaging with the fourfold wisdom, though it does not seem to be occurring on a large scale. And while conclusions on the effectiveness of Berry's fourfold wisdom can only be provisional at this early juncture, we can ascertain that where the conversation is occurring, green thinking and ecological practices follow. Questions remain: for instance, when engaging with the fourfold wisdom, are Catholics allowing each not only to affirm but to qualify and inform critically the wisdoms of the others? This aspect, as we have discussed, is important to Berry's aim.

Finally, Berry's fourfold wisdom must also be appreciated within a larger and arguably continuing occurrence within the Catholic tradition, that of the degree to which the tradition assimilates other wisdoms, as it had done with the Greek wisdom, and later in the Medieval period, with the Aristotelian system. Renewal is not new within the Catholic tradition. The aggiornamento inaugurated by Pope John XXIII encapsulated the explicit purpose of updating the church to function in modern society. Looking at modern society today with its decided plurality, Catholics seem to have embraced, in large measure, an era aptly described by Raimundo Panikkar as the "hyphenated Christian" [73], or what Paul Knitter more recently names "double-belonging" [74]. 
However, the extent and depth to which the Church faithful as a whole, including its hierarchy, will view the teachings and practices of other traditions is not clear. ${ }^{15}$ Succinctly, Berry underlines, "The traditional religions in themselves and out of their existing resources cannot deal with the problems that we have to deal with, but we cannot deal with these problems without the traditions" ([10], pp. 6-7). What seems clearer, as Berry avers himself, is that humanity today lives at a revelatory moment: the magnitude of our situation requires deep reflection from all religions as to why we have entered into the anthropocene, which will require momentous change. As we continue to make our mark as humans in the anthropocene, time is running out.

\section{Conflicts of Interest}

The author declares no conflict of interest.

\section{References}

1. Johan Rockström, Will Steffen, Kevin Noone, Åsa Persson, F. Stuart III Chapin, Eric Lambin, Timothy M. Lenton, Marten Scheffer, Carl Folke, Hans Joachim Schellnhuber, et al. "Planetary Boundaries: Exploring the Safe Operating Space for Humanity." Ecology and Society 14 (2009): article 32. Available online: http://www.ecologyandsociety.org/vol14/iss2/art32/ (accessed on 13 August 2013).

2. Will Steffen, Paul J. Crutzen, and John R. NcNeill. "The Anthropocene: Are Humans Now Overwhelming the Great Forces of Nature.” Ambio 36 (2007): 614-21.

3. Brian Thomas Swimme, and Mary Evelyn Tucker. Journey of the Universe. New Haven and London: Yale University Press, 2011.

4. John Grim, and Mary Evelyn Tucker. Ecology and Religion. Washington: Island Press, 2014.

5. The News Section of the Forum on Religion and Ecology, Yale. Available online: http://fore.yale.edu/news/ (accessed on 6 May 2015).

6. Cynthia Moe-Lobeda. Resisting Structural Evil: Love as Ecological-Economic Vocation. Minneapolis: Fortress Press, 2013.

7. Thomas Berry. The Dream of the Earth. San Francisco: Sierra Club Books, 1988.

8. Thomas Berry. The Christian Future and the Fate of the Earth. Edited by Mary Evelyn Tucker and John Grim. Maryknoll: Orbis Books, 2009.

9. Thomas Berry. Evening Thoughts: Reflecting on Earth as Sacred Community. Edited by Mary Evelyn Tucker. San Francisco: Sierra Club Books, 2006.

10. Thomas Berry. Befriending the Earth: A Theology of Reconciliation between Humans and the Earth. Edited by Stephen Dunn, C.P. and Anne Lonergan. Mystic: Twenty-Third Publications, 1995.

11. Robert P. Jones, Daniel Cox, and Juhem Navarro-Rivera. Believers, Sympathizers, and Skeptics: Why Some Americans Are Conflicted about Climate Change, Environmental Policy, and Science. Washington: Public Religion Research Institute in Association with the American Academy of Religion, 2014. Available online: http://publicreligion.org/research/2014/11/believers-sympathizers-

15 A good discussion on this broader issue, one that is still relevant today, can be found in a conversation amongst Mary Jo Leddy, Bishop Remi De Roo and Douglass Roche ([75], chapter 8). 
skeptics-americans-conflicted-climate-change-environmental-policy-science/\#.VWImRUZy_cY (accessed on 13 December 2014).

12. Anthony Leiserowitz, Edward Maibach, Connie Roser-Renouf, Geoff Feinberg, Seth Rosenthal, and Jennifer Marlon. Climate Change in the American Mind: Yale University and George Mason University. New Haven: Yale Project on Climate Change Communication, 2014. Available online: http://www.google.com/url?sa=t\&rct=j\&q=\&esrc=s\&source=web\&cd=3\&ved=0CC0QFjAC\&url $=$ http $\% 3 \mathrm{~A} \% 2 \mathrm{~F} \% 2 \mathrm{Fenvironment}$.yale.edu $\% 2 \mathrm{Fclimate}-$ communication $\% 2 \mathrm{Ffiles} \% 2 \mathrm{FClimate}-$ Change-American-Mind-October-2014.pdf\&ei=2xRqVaDkK4GLyAStyILoCw\&usg= AFQjCNEsTZsj78sDKwUiOHnNAyWwouvnlA\&bvm=bv.94455598,d.aWw\&cad=rja (accessed on 20 April 2015).

13. Natural Resources Defense Council. "Overwhelming Majority of Latinos Want Strong Presidential Action to Combat Climate Change, Poll Shows.” 23 January 2014. Available online: http://www.nrdc.org/media/2014/140123b.asp (accessed on 20 April 2015).

14. Latino Decisions. "Natural Resources Defense Council/Latino Decisions Survey_January 2014." Available online: http://www.latinodecisions.com/files/7913/9043/8102/NRDC_LD_Toplines_ January.pdf (accessed on 20 April 2015).

15. Larry Rasmussen. Earth-honoring Faith: Religious Ethics in a New Key. New York: Oxford University Press, 2013.

16. Annemarie C. Mayer. "The Second Vatican Council 50th Anniversary: Visions and Re-visions." International Journal for the Study of the Christian Church 14 (2014): 338-47. Available online: http://dx.doi.org/10.1080/1474225X.2014.997979 (accessed on 12 May 2015).

17. Thomas Berry. The Great Work: Our Way into the Future. New York: Bell Tower, 1999.

18. Heather Eaton. "Introduction." In The Intellectual Journey of Thomas Berry: Imagining the Earth Community. Edited by Heather Eaton. Lanham: Lexington Books, 2014, pp. x-xvii.

19. Brian Swimme, and Thomas Berry. The Universe Story: From the Primordial Flaring Forth to the Ecozoic Era, A Celebration of the Unfolding of the Cosmos. San Francisco: HarperSanFrancisco, 1992.

20. Mary Evelyn Tucker. "Thomas Berry." In The Encyclopedia of Religion and Nature. Edited by Bron Taylor. London: Thoemmes Continuum, 2005, pp. 164-66.

21. Mary Evelyn Tucker. "Thomas Berry and the New Story." Available online: http://www. thomasberry.org/Biography/tucker-bio.html (accessed on 12 December 2011).

22. Thomas Berry. "The Universe Story: Its Religious Significance." In The Greening of Faith: God, the Environment, and the Good Life. Edited by John Carroll, Paul Brockelman and Mary Westfall. Hanover: University of New Hampshire Press, 1997, pp. 208-18.

23. Ruben L.F. Habito. Healing Breath: Zen Spirituality for a Wounded Earth. Maryknoll: Orbis, 1993.

24. Thich Nhat Hanh. Peace is Every Step: The Path of Mindfulness in Everyday Life. Edited by Arnold Kotler. New York: Bantam Books, 1992.

25. Approved by the Bishops of Canada, Confirmed by the Holy See. The Roman Missal. Ottawa: Canadian Catholic Conference of Bishops, 2011.

26. John A. Grim. "Introduction." In Indigenous Traditions and Ecology: The Interbeing of Cosmology and Community. Edited by John Grim. Cambridge: Harvard University Center for the Study of World Religions, 2000. 
27. John Grim. "Thomas Berry and Indigenous Thought: First Nations and Communion with the Natural World." In The Intellectual Journey of Thomas Berry: Imagining the Earth Community. Edited by Heather Eaton. Lanham: Lexington Books, 2014, pp. 123-48.

28. Heather Eaton. "Response to Rosemary Radford Ruether: Ecofeminism and Theology — Challenges, Confrontations, and Reconstructions." In Christianity and Ecology: Seeking the Well-Being of Earth and Humans. Edited by Dieter T. Hessel and Rosemary Radford Ruether. Cambridge: Harvard University Press for the Harvard University Center for the Study of World Religions, 2000, pp. 113-24.

29. Rosemary Radford Ruether. Gaia and God: An Ecofeminist Theology of Earth Healing. San Francisco: HarperSanFrancisco, 1994.

30. Rosemary Radford Ruether. "Ecofeminism: The Challenge to Theology." In Christianity and Ecology: Seeking the Well-Being of Earth and Humans. Edited by Dieter T. Hessel and Rosemary Radford Ruether. Cambridge: Harvard University Press for the Harvard University Center for the Study of World Religions, 2000, pp. 97-112.

31. Rosemary Radford Ruether. "Ecofeminist Philosophy, Theology, and Ethics: A Comparative View." In Ecospirit: Religions and Philosophies for the Earth. Edited by Laurel Kearns and Catherine Keller. New York: Fordham University Press, 2007, pp. 77-93.

32. Rosemary Radford Ruether. Introducing Redemption in Christian Feminism. Sheffield: Sheffield Academic Press, 1998.

33. Rosemary Radford Ruether. "Toward an Ecological-Feminist Theology of Nature." In Readings in Ecology and Feminist Theology. Edited by Mary Heather Mackinnon and Moni McIntyre. Kansas City: Sheed and Ward, 1995, pp. 89-93.

34. Ivonne Gebara. Longing for Running Water: Ecofeminism and Liberation. Minneapolis: Fortress Press, 1999.

35. Steven Bouma-Prediger. The Greening of Theology: The Ecological Models of Rosemary Radford Ruether, Joseph Sittler, and Jurgen Moltmann. Atlanta: Scholars Press, 1995.

36. Rosemary Radford Ruether. Women and Redemption: A Theological History. Minneapolis: Fortress Press, 1998.

37. George E. Tinker. Spirit and Resistance: Political Theology and American Indian Liberation. Minneapolis: Fortress Press, 2004.

38. Gregory Cajete. "Indigenous Education and Ecology: Perspectives of an American Indian Educator." In Indigenous Traditions and Ecology: The Interbeing of Cosmology and Community. Edited by John A. Grim. Cambridge: Harvard University Press for the Center of the Study of World Religions, 2001, pp. 619-38.

39. John Grim. "Indigenous Knowing and Responsible Life in the World." In Ecospirit: Religions and Philosophies for the Earth. Edited by Laurel Kearns and Catherine Keller. New York: Fordham University Press, 2007, pp. 196-216.

40. Jean-François Lyotard. The Postmodern Condition: A Report on Knowledge. Translated by Geoff Bennington and Brian Massumi. Minneapolis: University of Minnesota Press, 1984.

41. Heather Eaton. "Cosmological Ethics? The Great Work." Worldviews: Environment Culture, Religion 52 (2001): 157-69. 
42. Lisa H. Sideris. "Science as Sacred Myth? Ecospirituality in the Anthropocene Age." In Linking Ecology and Ethics for a Changing World: Values, Philosophy, and Action. Edited by Ricardo Rozzi, S.T.A. Pickett, Clare Palmer, Juan J. Armesto and J. Baird Callicott. Dordrecht: Springer, 2013, pp. 147-62.

43. Mary Midgley. The Myths We Live By. London: Routledge, 2003.

44. David Tracy. Blessed Rage for Order: The New Pluralism in Theology. New York: Seabury Press, 1975.

45. Sarah McFarland Taylor. Green Sisters: A Spiritual Ecology. Cambridge: Harvard University Press, 2007.

46. Rita M. Gross, and Rosemary Radford Ruether. Religious Feminism and the Future of the Planet: A Christian-Buddhist Conversation. London: Continuum, 2001.

47. Dominican Life USA. "Dominican Sisters Attend Conference (The 2010 Sisters of Earth Conference on two of Thomas Berry's Fourfold Wisdom)." Available online: http://www. domlife.org/2010Stories/soe_conference.htm (accessed on 6 May 2015).

48. The Passion of the Earth. Available online: http://www.stgertrudes.org/passionoftheearth.html (accessed on 6 May 2015).

49. Genesis Farm. Available online: http://www.genesisfarm.org/about.taf (accessed on 8 May 2015).

50. Ignatius Jesuit Centre of Guelph. Available online: http://ignatiusguelph.ca/land/index.html (accessed on 6 May 2015).

51. Ignatius Jesuit Centre Guelph. "The Greening of the Spiritual Exercises." Available online: http://www.orientations/greening.html (accessed on 6 May 2015).

52. Archdiocese of Regina. "Holy Yoga Classes." Available online: http://archregina.sk.ca/news/ 2014/4/3/holy-yoga-classes (accessed on 6 May 2015).

53. Marco Tosatti. "Vescovo Italiano Apre a Yoga." La Stampa, 16 February 2013. Available online: http://www.lastampa.it/2013/02/16/blogs/san-pietro-e-dintorni/vescovo-italiano-apre-a-yogaEzNXHuxrFuzRep0HPRZmDN/pagina.html (accessed on 6 May 2015).

54. Sr. Priscilla Solomon. "Welcoming Water Ritual." Available online: www.kairoscanada.org/wp./ DR-IR-OWOL-WelcomingWaterRitual.pdf (accessed on 6 May 2015).

55. Kateri Television. "Medicine Wheel: Healing and Reconciliation as Social Justice." Available online: http://www.villagersmedia.com/kateritv/kv01e06.html (accessed on 6 May 2015).

56. Saint Regis Catholic Mission Church. Available online: http://narrative.ly/personal-jesus/wheresunday-mass-is-in-mohawk/\# (accessed on 7 May 2015).

57. Erin Brohman. "N.W.T. Parish Divided over Incorporating Aboriginal Practices." $C B C$ News, 20 July 2014. Available online: http://www.cbc.ca/news/canada/north/n-w-t-parish-divided-overincorporating-aboriginal-practices-1.2708186 (accessed on 6 May 2015).

58. Vatican Pontifical Council's. "Jesus Christ the Bearer of the Water of Life: A Christian Reflection on the 'New Age'." Available online: http://www.vatican.va/roman_curia/pontifical_councils/ interelg/documents/rc_pc_interelg_doc_20030203_new-age_en.html (accessed on 14 May 2003).

59. Joseph Card Ratzinger. "Letter to the Bishops of the Catholic Church on Some Aspects of Christian Meditation.” 15 October 1989. Available online: http://www.vatican.va/roman_curia /congregations/cfaith/documents/rc_con_cfaith_doc_19891015_meditazione-cristiana_en.html (accessed on 14 May 2015). 
60. Pope Benedict. "Message of His Holiness Pope Benedict XVI for the Celebration of the World Day of Peace." 1 January 2010. Available online: http://w2.vatican.va/content/benedict-xvi/ en/messages/peace/documents/hf_ben-xvi_mes_20091208_xliii-world-day-peace.html (accessed on 12 January 2011).

61. The Holy See. "Doctrinal Assessment of the Leadership Conference of Women Religious." 18 April 2012. Available online: http://www.vatican.va/roman_curia/congregations/cfaith/ documents/rc_con_cfaith_doc_20120418_assessment-lcwr_en.html (accessed on 12 May 2015).

62. Laurie Goodstein. "Vatican Ends Battle with U.S. Catholic Nuns' Group." New York Times, 16 April 2015. Available online: http://www.nytimes.com/2015/04/17/us/catholic-church-endstakeover-of-leadership-conference-of-women-religious.html?_r=0 (accessed on 17 April 2015).

63. Cardinal João Braz de Aviz. "Final Report on the Apostolic Visitation of Institutes of Women Religious in the United States of America." 8 September 2014. Available online: http://press. vatican.va/content/salastampa/en/bollettino/pubblico/2014/12/16/0963/02078.html (accessed on 12 May 2015).

64. John Hart. "Catholicism." In The Oxford Handbook of Religion and Ecology. Edited by Roger S. Gottlieb. New York: Oxford University Press, 2006, pp. 64-91.

65. The Holy See. "III Extraordinary General Assembly: The Pastoral Challenges of the Family in the Context of Evangelization.” 2014. Available online: http://www.vatican.va/roman_curia/synod/ documents/rc_synod_doc_20140626_instrumentum-laboris-familia_en.html (accessed on 12 May 2015).

66. Jamie Manson. "Panel Contemplates Why the Papal Encyclical on the Environment Will Matter." National Catholic Reporter, 15 April 2015. Available online: http://ncronline.org/blogs/gracemargins/panel-contemplates-why-papal-encyclical-environment-will-matter (accessed on 16 April 2015).

67. Donal Dorr. “'The Fragile World': Church Teaching on Ecology before and by Francis.” Thinking Faith, February 2014. Available online: http://www.thinkingfaith.org/archive/2014/02 (accessed on 12 November 2014).

68. Christiana Z. Peppard. "A Planetary Hope." America: The National Catholic Review, 2015. Available online: http://americamagazine.org/issue/planetary-pope (accessed on 2 June 2015).

69. Brian Roewe. "Conservative Corners Have Tepid Take on Pope Francis' Environment Encyclical.” National Catholic Reporter, 21 April 2015. Available online: http://ncronline.org/ blogs/eco-catholic/conservative-corners-have-tepid-take-pope-francis-environment-encyclical (accessed on 22 April 2015).

70. The Forum on Religion and Ecology at Yale. "News." Available online: http://www. fore.yale.edu/news/ (accessed on 22 June 2015).

71. Pope John Paul II. "Message of His Holiness, Pope John Paul II for the Celebration of the World Day of Peace.” 1 January 1990. Available online: http://www.vatican.va/holy_father/john_paul_ ii/messages/peace/documents/hf_jp-ii_mes_19891208_xxiii-world-day-for-peace_en.html (accessed on 12 April 2004).

72. Pope Francis. "Laudato Si: On Care for Our Common Home." 18 June 2015. Available online: http://w2.vatican.va/content/francesco/en/encyclicals/documents/papa-francesco_20150524_ enciclica-laudato-si.html (accessed on 18 June 2015). 
73. Raimundo Panikkar. The Interreligious Dialogue. New York: Paulist Press, 1978.

74. Paul F. Knitter. Without Buddha I could not be a Christian. Oxford: Oneworld, 2009.

75. Mary Jo Leddy, Bishop Remi De Roo, and Douglass Roche. The Eye of the Catholic Storm: The Church since Vatican II. Edited by Michael Creal. Toronto: HarperCollins, 1992.

(C) 2015 by the author; licensee MDPI, Basel, Switzerland. This article is an open access article distributed under the terms and conditions of the Creative Commons Attribution license (http://creativecommons.org/licenses/by/4.0/). 